\title{
The social dimension in energy landscapes
}

\author{
Alessandra Bianchi ${ }^{*}$ (D) and Elisabetta Ginelli²
}

\begin{abstract}
If, nowadays, the Communities' welfare lies in new expressions of collaboration between different types of subjects for the achievement of common objectives, cultural consensus becomes the collective transformation tool to promote regeneration interventions of life contexts encouraged by new social innovation ideas such as products, services and models. This research considers five aspects of the social dimension to define energy systems location and their acceptability. In particular: social equity: as a fair distribution of costs and risks throughout society; spatial equity: as a fair distribution of risks and costs throughout the territory; intergenerational equity: as a proper assessment of the risks that would entail current locations for future generations; procedural equity: when the location decisions and the same decision making process are perceived as legitimate by all concerned; equity structural: when the localization process involves all aspects and interests, leaving no one out for their approaches (Murphy and Stanley 2006). In relation to the analyzed aspects, this study suggests a point of view on the role of reasoning and interpreting the social activity of individuals in relation to bottom-up decision-making processes for the formation of cultural consensus when changes in the usual life and environmental contexts occur.
\end{abstract}

\section{The elements for the comprehension of the social aspects connected to the energy/landscape systems relation: cultural consensus for the localization of energy systems and system acceptability}

If landscape is considered as interaction between natural elements and human activities seen as a whole with the environment's historical evolution process that is continuously subject to changes, due to the effect of natural processes and of human interventions, it can then be described, according to different levels of detail, through the analysis of its key components: the natural, the anthropic-cultural and perceptual components. The perceptual component includes both aspects relating to places' identification characters and connotation, as the more strictly aesthetic.

A first analysis of the relationships between human component and landscape, in fact, can be reconnected to the concepts of perception (what comes from external stimuli through the senses) and cognition (the brain processing result of what is perceived). These two aspects must be considered jointly because no sensory

\footnotetext{
*Correspondence: alessandra.bianchi@bbs.unibo.it

1 Bologna Business School, Università degli Studi di Bologna, Via degli

Scalini, 18, 40136 Bologna, Italy

Full list of author information is available at the end of the article
}

perception is sufficient condition to understand the environment that does not only have physical but also emotional characteristics. ${ }^{1}$ If we base on a concept connected to the interaction between the individual and the surrounding environment, we can state that the surroundings' characteristics directly affect the individual's responses, as the environment is seen as cause and the individual's behavior as effect.

Learning and knowledge level influence the genetic component, which makes us perceive the senses and, they both allow changes in perceptions.

This analysis leads to the study of the descriptions and representations of a particular landscape synthesized in time, to the examination of the various constraints-if there are- and to the different organizational strategies of the settlements expressed by communities that lived or live in that landscape.

"The energy challenge is likely to become a central element in development strategies at all levels. Renewable energies are the future. They help build a better world and to make humane sustainable development" (Fusco Girard and Nijkamp 2004). ${ }^{2}$ This challenge, that is growing rapidly and of which, increasingly we see the results,

\footnotetext{
${ }^{1}$ For further considerations see: Di Giovanni (2000) and Farina (2006).

${ }^{2}$ See also: Fusco Girard (2011), (Fusco Girard and Salzano 2005).
} 
however, modifies the landscape and changes are not always positively accepted by human society that claims its' spaces and habits.

In recent years, with the increase in number of renewable energy plants, ${ }^{3}$ we can observe a so far mostly ignored factor that frequently turns out to be an obstacle for the development of projects: social acceptance.

This aspect has been neglected in the $80 \mathrm{~s}$, period in which the programs for the creation of energy policies were launched. Surveys carried out then, demonstrated that the community accepted extensively the energy production technologies from renewable sources, therefore politicians, developers, companies and local authorities did not consider the issue of social acceptance. The first problems arose when it was necessary to decide where to install the first wind turbines: the site selection often turned out to be a problem involving a large number of actors with sometimes diametrically opposed interests. Nevertheless, until the 90s the social acceptance issue was never investigated (Wüstenhagen et al. 2007).

In the current, international research framework, energy debates still tend to underemphasize changes and consequences that energy systems can have on communities and landscapes. As Abramsky states, ${ }^{4}$ solutions for renewing the energy sector must include massive shifts in our use of technologies and, most importantly, a democratization of the economic landscape based on broad new coalitions. Energy debates need to be informed by robust empirical and theoretical inquiries into what current and future energy changes will mean for diverse groups of people around the earth. In the last years, energy systems infrastructure, ${ }^{5}$ economic aspects, engineering schemes, algorithms, risk management and some models of public engagement in scientific and technological decisionmaking, ${ }^{6}$ have been analyzed. Nevertheless and since there is increasing societal interest in democratic participation in technological change, social problems related to changes induced by energy systems, have not yet been thoroughly investigated. The proposed model, intends to fill the existing social gap in siting decisions and acceptability and to highlight the relevance of a new concept: cultural consensus for successful energy development plans.

\footnotetext{
${ }^{3}$ See Ref. Brovarone and Putilli (2008), EEA-European Environment Agency (2008), Marchigiani and Prestamburgo (2010, 2012).

4 See Ref. Abramsky (2010).

5 See Ref. Edwards et al. (2009). For energy systems infrastructures and their relationship with landscape see: Ginelli and Daglio (2014a, b, 2015).

${ }^{6}$ See Ref. Sclove (1995).

See Ref. Kleinman (2000)

See Ref. Phadke (2013).

See Ref. Cowell et al. (2011).

See Ref. Miller (2012).
}

According to Weber, social order is the result of cultural consensus that takes place between individuals of a community that share common aspirations and values. The reiteration of these tendencies explains the recurrence of individual actions and then leads to the formation of lifestyles.

Hence the need for a widespread cultural consensus that will enable the development of projects and the active participation of the population by strengthening cooperation and reducing conflict.

The interpretation of landscape in consideration of cultural consensus, must be multi-temporal and inter-disciplinary. The different knowledge must be combined to the different trends for the planning of actions or modification interventions.

Starting from the definition given by Wüstenhagen Wolsink and Burer of social acceptance, that includes three interrelated dimensions, such as: socio-political acceptance, community acceptance and market acceptance, we realize that it also includes the policy makers category in the socio-political acceptance dimension.

The other two dimensions, focused respectively on the community acceptance in relation to the choice of sites for the plants installation (also includes the attachment to places, ${ }^{7}$ the landscape identity and procedural equity) and on the acceptance in relation to the process of market adoption and implementation of an innovation are an aid to better understand the creation of consensus by local communities (bottom-up) and then the full acceptance of a system (Fig. 1).

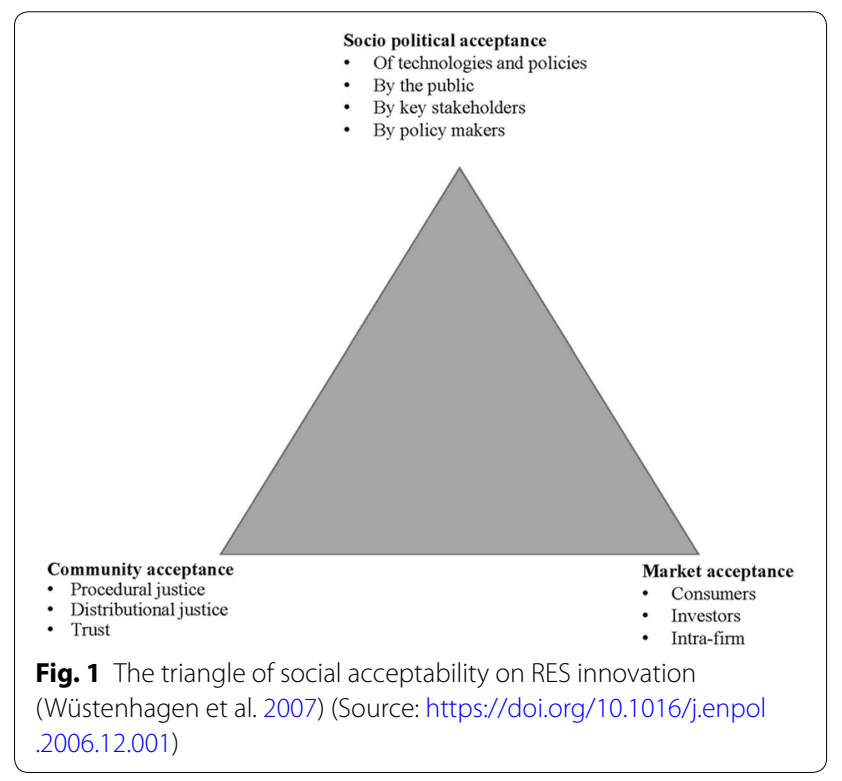

${ }^{7}$ On this topic, for an interesting analysis see: Devine-Wright and Batel (2017). 
A study on the acceptability of wind farms (Wolsink $2007 \mathrm{a}, \mathrm{b}$ ) shows that the community acceptance follows a U-shaped curve. Communities give a good support early on when they have to express their support "in general". The acceptability decreases strongly when they have to deal with the proposal of a project in their area of residence and then up to a good level of acceptance after the construction.

As for the market acceptance, this considers both consumers and investors. An example is the Energy Community that identifies sets of industrial, commercial or residential consumptions that, to meet their energy needs, decide to adopt a collegial approach based on distributed generation and smart energy management. ${ }^{8}$ The involved technologies are those required to produce energy locally, manage it, store it and monitor the flows through a collective and coordinated use that maximizes the benefits. ${ }^{9}$

It is therefore necessary to identify methods of analysis and assessment for the management of the relationship between energy systems and landscapes through phases that involve knowledge, evaluation and assessments using tools that enable repeatable procedures based on standards of acceptability for diversified operations ${ }^{10}$.

\section{The bottom-up decision-making processes}

Quoting the British sociologist Roland Robertson "think global act local" (Robertson 1992) we can clearly understand how the bottom-up initiatives are often the most positive and relevant in terms of actions aimed at a sustainable and conscious development such as those relating to the emissions reduction, especially at a time when the 'top' policies have recorded some failures. ${ }^{11}$

We must consider that the economic-social system of advanced societies has been planned and developed in a centralized way around conventional energy (oil, gas, coal, nuclear), and in particular, on the production of electricity from large power plants. New renewables assume, conversely, a decentralized system based on small plants, with a strong link with the land whose natural resources (wind, water, sun, vegetation, etc.) supply the power plants.

Until renewable systems were limited to some traditional sources (e.g. hydropower) settled in confined areas, there were no particular problems in integrating them

\footnotetext{
${ }^{8}$ See Ref. Friedl and Reichl (2016).

${ }^{9}$ See Refs. Mallett (2007) and Melis (2010).

10 On wind energy acceptance see also: Rand and Hoen (2017).

${ }^{11}$ For further readings on this topic see: Refs. Kellet (2007) and Walters (1986).
}

into the local contexts. The development of renewable energy on a larger scale, very often implemented without considering land planning, has highlighted problems that had not been taken into account up to that point. ${ }^{12}$

Given that the identification as elements of a network generates awareness that relations allow the development of each one's identity, for the creation of collective actions, we must consider the aspect of the envisioning: to elicit visions of sustainability to stimulate people in critical thinking, responsibility, assumption of choices through the knowledge and perceptions of well-being. To address the impact of globalization people feel the need to transform the cities and common areas in areas of solidarity and to acknowledge local institutions their power increasing citizens' participation. Glocal combines global and local in an attempt of harmonizing the impact of globalization that tends to even out in standard and abstract logics, the social, cultural and economic peculiarities of determined areas proposing a new interconnection ethics ${ }^{13}$ useful to:

- Give attention to civil society at all decision making levels to define projects for a more equitable and sustainable future;

- Represent the instances of civil society in the debates and in public policy-making processes;

- Strengthen and integrate the international network of projects, actions and initiatives that are an important collective resource;

- Promote environmental education to achieve collective awareness of its importance. ${ }^{14}$

In the renewable energies field the concept of Glocal allows to:

\footnotetext{
12 See Refs. Dincer and Rosen (2007), Elliot (2003), Kaygusuz (2007).

13 A new interconnection ethics can be achieved if communities go beyond rivalries that become an obstacle to new experiments.

14 From the Milan Charter drafted by the "Coordination Board for the redaction of the Milan Charter", Milano 2015.

Ministry for Agricolture, Food and Forestry Policies.Steering Committee for the EU Scientific Programme for EXPO 2015-Milan Municipality.

Ministry of Foreign Affairs and International Cooperation.

Ministry for Environment, Land and Sea.

Ministry of Health.

UN-United Nations.

FAO_Food and Agriculture Organization.

President of the Steering Committee of the Participant Countries.

Commissioners.

Expo Milano 2015.

Padiglione Italia.

Laboratorio Expo-Fondazione Giangiacomo Feltrinelli.

We-Women for Expo.Feeding Knowledge.

Food Waste Observatory-University of Bologna.

Triulza Foundation.

Barilla Center for Food and Nutrition.
} 
- Develop and implement integrated strategies for the reduction of climate change, and move towards a sustainable level of greenhouse gas emissions considering the central role of climate protection in the fields of energy, transport, waste, agriculture and forestation.

- Raise awareness of the causes and probable impacts of climate change, and integrate preventive actions into the climate protection strategies.

- Strengthen international cooperation among cities and develop local responses to global problems in partnership with local governments, communities and NGOs.

How local actors act in relation to the available resources and the links they establish between them, must be related to the environment in which they operate. Land districts are unquestionably a required resource to enable change processes and the place to promote relationships networks, but the different players must prove themselves able to identify a functional design for a possible development for that site and create the needed conditions to accomplish it. To accomplish development and make it stable is therefore essential for the context to be able to understand the renovation opportunities and to conciliate them to pre-existing conditions.

$\mathrm{RES}^{15}$ are a heterogeneous set of energy sources and people differently perceive them.

In terms of acceptability, biomass seems the most penalized for three main reasons: (i) energy conversion is performed through the combustion process with the emissions in the exhaust pipe of potential pollutants. Combustion is perceived as a negative element and it often becomes synonymous of air pollution: this explains why, for example environmental organizations in the US have proposed not to consider renewable all sources based on combustion; (ii) the assimilation of biomass waste, the incineration of which arouses strong opposition for fear of the possible emissions of toxic products (especially dioxins). In some cases, the opposition to the biomass plants processed by forestry residues comes from the fear that they are instead used to achieve the

\footnotetext{
${ }^{15}$ RES are Renewable Energy Sources. According to the IEA (International Energy Agency), renewable energy sources can be grouped into the following categories: a. Biomass, biofuels and waste: solid biomass, animal products, biomass gases/liquids, solid urban waste (renewable portion); b. Hydraulic energy: large \& small hydro; c. Alternative or new sources: geothermal energy, solar energy (thermal and photovoltaics), wind energy, tides, waves and oceans energy. while, the classification according to ENEA (Italian National Agency for New Technologies, Energy and Sustainable Economic Development), is broader. In addition to the renewable energy sources classified by the IEA, ENEA includes among biomass, all the solid urban waste portions and the category "wood and similar".
}

real goal (incineration of $\mathrm{MSW}^{16}$ ). (iii) the lack of information and involvement of the concerned communities by Institutional-non local- Bodies (top-down projects, exclusion from decision-making, information asymmetry on the objectives, political struggle, consensus, acceptability). ${ }^{17}$

The exclusively top-down approaches often cause conflicts and are scarcely credible today because of their contradictions and of the few knowledge tools given to citizens, that nowadays, tend to enhance local peculiarities as propellers of development and want to participate to the changes of their surroundings. ${ }^{18}$

The consequences of these conflicts, in relation to renewable energy systems, are connected to their social non-acceptance and even in case of dispute and/or opposition that ends up anyway with the installation of the new energy system, it causes a delay and the time expectations will not be met. Uncertainties related to implementation timing mean for proposers (which invested, among other, significant economic resources) evident damage.

However, the bottom-up decision-making process must be interpreted correctly, that means that it has to be combined to the concept of cultural consensus formation that makes acceptable a particular RES plant system and its location be given by the collective construction of landscape. More precisely, a collective construction of the social representation of landscape that indirectly addresses the individual and collective choices and actions that are the origin of transformations. The landscape itself can represent a tool for the creation of common goals.

\footnotetext{
${ }^{16}$ MSW stands for Municipal Solid Waste. These include waste generated in residential settlements and in public areas. The definition is given by the Decree. n. 152/2006, art. 184, paragraph 2 in which municipal waste is defined as: (a) household waste, as well as bulky waste, from areas used for residential purposes;

(b) non-hazardous waste from premises and sites used for different purposes than those referred to in subparagraph a), treated as municipal waste in terms of quantity and quality, in accordance with article 198, paragraph 2, letter g);

(c) waste originating from street sweeping;

(d) waste of any kind or origin, lying on public streets and areas or on private streets and areas subject to public use or on sea and lake beaches and on the waterways' banks;

(e) vegetal waste from green areas, such as gardens, parks and cemeteries;

(f) waste from exhumation and disinterment as well as other waste from cemeteries other than those referred to in subparagraphs (b), (c) and (e).

17 Cfr, Italian Biomass Association (ITABIA), I traguardi della bioenergia in Italia, Rapporto 2008-elementi chiave per gli obiettivi al 2020, dibattito sui criteri di sostenibilità, formulazioni metodologiche, addenda and also: L'accettabilità sociale degli impianti a biomasse e biogas, ARPAT news n. 36, 20.02.2015-http://www.arpat.toscana.it/notizie/arpatnews.

18 See Ref. Huber et al. (2017).
} 


\section{The system fairness concept}

When considering renewable sources energy systems related to the social dimension, we face a paradox: renewables are essential to combat pollution from traditional energy sources, but a problem emerges when it comes to plants location (especially with incinerators, biomass plants and wind turbines). All communities derive benefits from the existence of a renewable energy system while the negative externalities are transferred only to the community hosting the facility. The NIMBY (Not In My Backyard) ${ }^{19}$ or LULU (Locally Unwanted Land Use ${ }^{20}$ phenomena arise and lead us to think about the disputes on the localization projects. ${ }^{21}$

Analogously, a research by Laurent-Lucchetti and Leroux, ${ }^{22}$ states that the opposition reaction to localization projects by local actors is determined by the perception of their unfairness (inequity perception): benefits for society as a whole and costs focused on the local community.

When analyzing the principle of equity, as assumed in the concept of sustainable development, that ensures the proper distribution of burdens and benefits of each policy and in each sector over time and space, some considerations have to be done on a local, regional, national or global scale and evaluating a time frame.

For the energy systems locations but also for the choice of the system, we can consider the following five aspects reprocessed in a perspective linked to renewable energy systems and their interaction with landscape, on the basis of principles endorsed from the concept of environmental justice ${ }^{23}$ and used for the strategies related to the radioactive waste management:

- Social equity: a fair distribution of costs and risks throughout society;

\footnotetext{
19 The term NIMBY, first used in the early 80s, indicates "the protectionist attitudes and exclusionary/oppositional tactics adopted by community groups facing an unwelcome development in their neighbourhood". (Wolch and Dear 1993).

20 The term LULU was coined by Frank Popper in 1981 to indicate an undesirable local land use.

21 For further considerations see also: Armour (1991) and Caramis (2010).

22 See Ref. Laurent-Lucchetti and Leroux (2007).

23 The definition of Environmental Justice given by the USA Environment Protection Agency EPA- http://www.epa.gov: "Environmental Justice is the fair treatment and meaningful involvement of all people regardless of race, color, national origin, or income with respect to the development, implementation, and enforcement of environmental laws, regulations, and policies". EPA has this goal for all communities and persons across the nation. It will be achieved when everyone enjoys the same degree of protection from environmental and health hazards and will have equal access to the decision-making process to have a healthy environment in which to live, learn and work.
}

- Spatial equity: a fair distribution of risks and costs throughout the territory;

- Intergenerational equity: a fair assessment of the risks that would entail current locations for future generations;

- Procedural equity: location decisions and the same decision making process are perceived as legitimate by all concerned communities;

- Structural equity: when the localization process involves all aspects and interests.

Social equity, along with precautionary and subsidiarity principles, ${ }^{24}$ is one of the basic principles of sustainable development and Agenda 21. It places human beings (as part of a society) as center of concerns (communities, the relationship between them or individuals). The balance in society is governed by rules relating to forms of fair trade. We achieve an equitable relationship when the same distribution of costs and benefits is perceived. When instabilities are perceived, these can be considered as risks related to the location of an ES in a specific area (NIMBY phenomena).

The spatial equity diverging from social equity focuses on the territory. It can be interpreted by using the concept of $\operatorname{space}^{25}$ as a dimension in relation to location choices, to the configuration of territorial systems, the greater or lesser development of an area and the distribution of activities in space. It highlights the factors that influence the system location choices, through the distribution of activities in space and the various local communities. When the resident community has the perception of a loss of control over the area of influence of an ES, LULU phenomena are likely to arise, highlighting the existence of conflicts related to the perception of the loss of identity of an area and of the origination of non-places in highly recognizable contexts.

The intergenerational equity assumes that the environment belongs to everyone and everyone should enjoy equally its resources for a better life quality. An equity in the distribution and potential uses of the resources and services generated by the ES between present and future generations.

\footnotetext{
${ }^{24}$ The precautionary principle states that, in cases of serious or irreversible threats to the health of humans or ecosystems, acknowledged scientific uncertainty should not be used as a reason to postpone preventive measures. The subsidiarity principle recommends the cooperation of all the legal and government bodies for the social and ecological survival and for the defense of human rights and health. It commits States to cooperate in the promotion of sustainable development in the interest of single states and of the entire international community, according to the approach of "common but differentiated responsibility".

25 In the spatial equity principle space is to consider as "physical-metric space" unlike social equity where space is to consider as "relational space".
} 
The procedural equity proposes fair rules and equality of opportunity for all members of a community that have the opportunity to achieve a satisfactory project. It's connected to the procedures with which communities come to an agreement and to the interaction and communication system developed during the decisionmaking process. The evaluation criteria may include: the use of objective information during the decision-making process, the use of neutral third parties, the fair exchange of information and the consistency of decisions over time (Steg et al. 2013).

The structural equity considers that during the localization process, broader societal contexts and policies (e.g. energy/waste policies, power position of stakeholders) that may unfairly impinge particular stakeholder groups must be acknowledged and addressed during the siting process (Murphy and Kuhn 2006). Structural equity is achieved when the localization process involves all aspects and all interests of the communities in the area of influence of the ES.

On the basis of the well-known, study cases of Gussing $^{26}$ (Koch et al. 2006) and Dardesheim, ${ }^{27}$ the reference scenario demonstrates how the use of renewable energy systems, creates opportunities for democratic energy development and for the formation of cultural consensus, that, settles in time and becomes part of a communities' life style, to achieve the fulfillment of equity principles.

One of the here examined study cases, ${ }^{28}$ that shows that it is possible to meet all the equity principles, is the Vauban sustainable district in Freiburg (Wienke 2001).

\footnotetext{
${ }^{26}$ By 2001, Gussing, a small town in the Burgenland region of Austria, was energy self-sufficient, a magnet for eco-tourists, and an important industrial center due to the combination of substantial improvements in energy efficiency and deployment of renewable energy technologies. Producing biodiesel from local rapeseed and used cooking oil, and heat and power from the sun and through biomass steam gasification, the community reportedly became the first in the European Union (EU) to meet 100\% of its energy demand with renewable sources. The transition started in 1992, when Gussing was a combination of poor economy, low employment and large amounts of money spent for energy imports. See for example Müller M. O. Stämpfli A. Dold U. Hammer T., Energy autarky: A conceptual framework for sustainable regional development in Energy Policy, Volume 39, Issue 10, October 2011, pp 5800-5810, Elsevier and Marcelja, D. Self-sufficient community: Vision or reality? Creating a regional renewable energy supply network (Güssing, Austria). In Local Governments and Climate Change, 39th ed.; Van Staden M, Musco F, Eds; 2010; pp 217-228.

${ }^{27}$ Dardesheim is a perfect example of the potential of community power. A small rural village located in the state of Saxony Anhalt (former East Germany), since the early 1990s, it has managed to install 31 wind turbines just outside the town, which have an installed capacity of $66 \mathrm{MW}$. The town gets $100 \%$ of its energy from renewable sources such as solar wind and biomass. Only local residents are allowed to become partners, and approximately $90 \%$ of the village's residents are involved, but the community's investment in renewables has become a development engine for the entire region encouraging local job creation. See Ref. (Hunter and Cohen 2011).

${ }^{28}$ For Freiburg and other study cases see: EEA-European Environment Agency (2001).
}

Social equity is given by the "Energy plus" residential units in which each citizen has the same distribution of costs and benefits; by participation in decision-making processes with bottom-up initiatives accepted by the Municipality; by the integration and diversity enhancement through the financing of social housing and cultural and symbolic initiatives.

The spatial equity is given by urban gardening that assembles the territorial system through a distribution of activities in spaces.

The intergenerational equity is granted by a sustainable mobility policy for the reduction of $\mathrm{CO}_{2}$ emissions; by the protection of the historical center; by the promotion of "anti-sprawl" urban initiatives; energy savings; the enhancement of open spaces.

The procedural equity is formalized through the urban plan of the Vauban district that achieves the objectives of a community-driven neighborhood with zero emissions. The planning process is divided into several phases. It starts with the definition, by the planning office, of a structure scheme, then the proposal is discussed within the City Council, then with the citizenship. At this point the "Vauban Forum" is established: for a permanent monitoring between the Administration and inhabitants. The records of the town meetings provide insight into the planning scheme and draw up guidelines on transport, environment and energy. This set of options is actualized in the final master plan.

The structural equity is satisfied because all aspects and all interests of the resident community are considered. In fact, the eco-community of Vauban hosts 5000 residents in housing units that use renewable energy and that have large common areas. Cycle paths now run for more than $500 \mathrm{~km}$. The trolley network is composed of four lines and runs for over $30 \mathrm{~km}$ and in 1973 the center was closed to traffic. In 1984 regional transport was established (tariff integration today is about 90 lines for more than $2800 \mathrm{~km}$ ). The results: decreasing car use, increased use of public transport and cycling, lower subsidies for public transport, very low accident rate (Fig. 2).

Another strongly representative example of the satisfaction of all the above mentioned equity conditions is the Italian Municipality of Prato allo Stelvio.

Prato allo Stelvio, a town of 3200 inhabitants located in the Alta Val Venosta (Bz), implemented a mix of different technologies ${ }^{29}$ through which it manages to cover with local and renewable resources the entire energy needs of its population.

\footnotetext{
${ }^{29} 6$ technologies form the energy mix: 4 district heating plants from biomass with a total rated thermal input of 7.4 MW, 210 thermo-solar plants covering $2.200 \mathrm{~m}^{2}, 5$ mini-hydro plants with a total of $4.082 \mathrm{~kW}$ e 141 solar plants with a total rated input of $6.87 \mathrm{MW}$.
} 

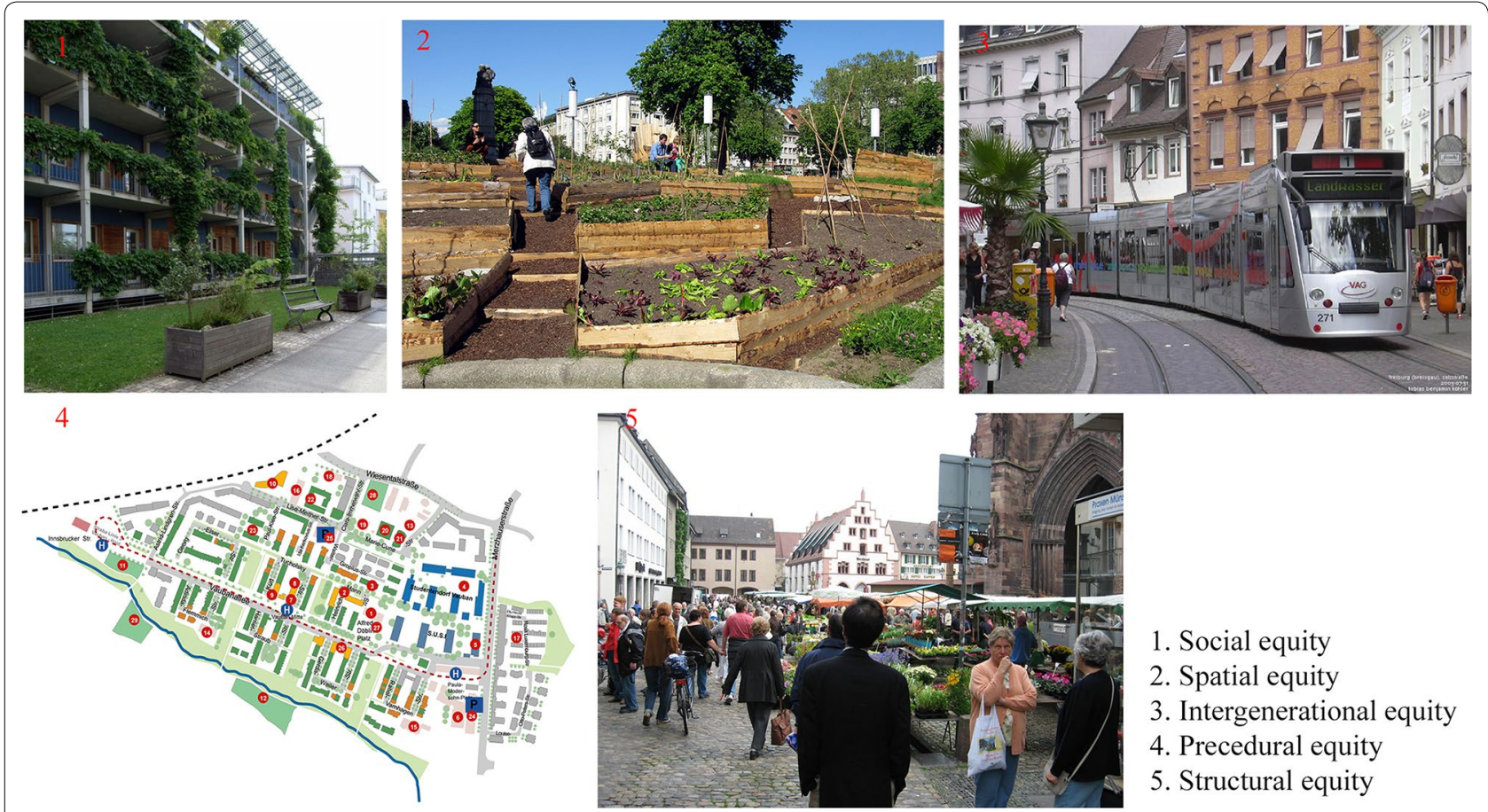

1. Social equity

2. Spatial equity

3. Intergenerational equity

4. Precedural equity

5. Structural equity

Fig. 2 The principle of equity postulated in the concept of sustainable development in the interventions realized in Freiburg GE (Source: 1. http:// www.ecoquartiers-geneve.ch/index.php?page=vauban-2. https://commons.wikimedia.org/wiki/File:Urban_Gardening_vor_dem_Theater_Freib urg.jpg-3. http://familypedia.wikia.com/wiki/Freiburg_im_Breisgau4. https://freiburg-vauban.de/en/quartier-vauban-2/-5. http://flatironbi ke.com/2013/04/04/sustainable-transportation-in-freiburg/)

The driving force behind the Prato allo Stelvio model is the local social Cooperative, E-Werk Prad, founded in 1926, that manages all the electricity distribution services, heating and recently also of those of broadband telecommunications through optical fibers. The cooperative owns the electrical and heating network and operates 17 renewable plants that fuel them and that are able to cover the entire municipality energy needs.

Social equity is given by the fact that almost all the inhabitants of the municipality are members of the Cooperative that counts 1148 members that consume $85 \%$ of the produced energy, involving almost all the families of Prato and the Municipality itself. The citizen is at the same time user, consumer and shareholder of the company that provides the service.

The spatial equity, placing its focus on the territory, considers the small size of the hydropower stations and their housing in low buildings with a wooden roof. In addition, in the occasion of the district heating systems undergrounding, power lines were also installed underground allowing the consequent elimination of the airlines and their infrastructures.

The intergenerational equity is given by the system created in Prato allo Stelvio itself. In fact it allows fairness in the distribution and in ES resources and services potential uses among past, present and future generations. In addition, the project, to improve the plants management efficiency in connection to the variability of demand and production from renewable sources, plans to build an energy storage in one of the hydroelectric plants (with a drop of $840 \mathrm{~m}$ ) through a pumping station.

The procedural equity is demonstrated by active participation in decisions by the entire community, i.e. all members of the Cooperative. The general shareholders' meeting, in which members vote general orientation and choices, is held every year. ${ }^{30}$

The structural equity is satisfied because the localization process involves all aspects and all interests of the communities in the area of influence of the ES. In fact, the electric utilities circuit serves 1600 consumers, 580 of which are connected to district heating, while 250 consumers benefit of broadband services. Members besides having clean energy benefit from substantial savings: they pay $0.12 € / \mathrm{kWh}$ (compared to about 0.19 of the protected categories market AEEG) and for the heating about 0.07

\footnotetext{
30 The underlying spirit is to work for their own welfare and to get services for their families. With a cultural consensus formed since the generation of the early 1900 s that created a mindset shaped by a nearly century-old cultural background also in the new generations.
} 

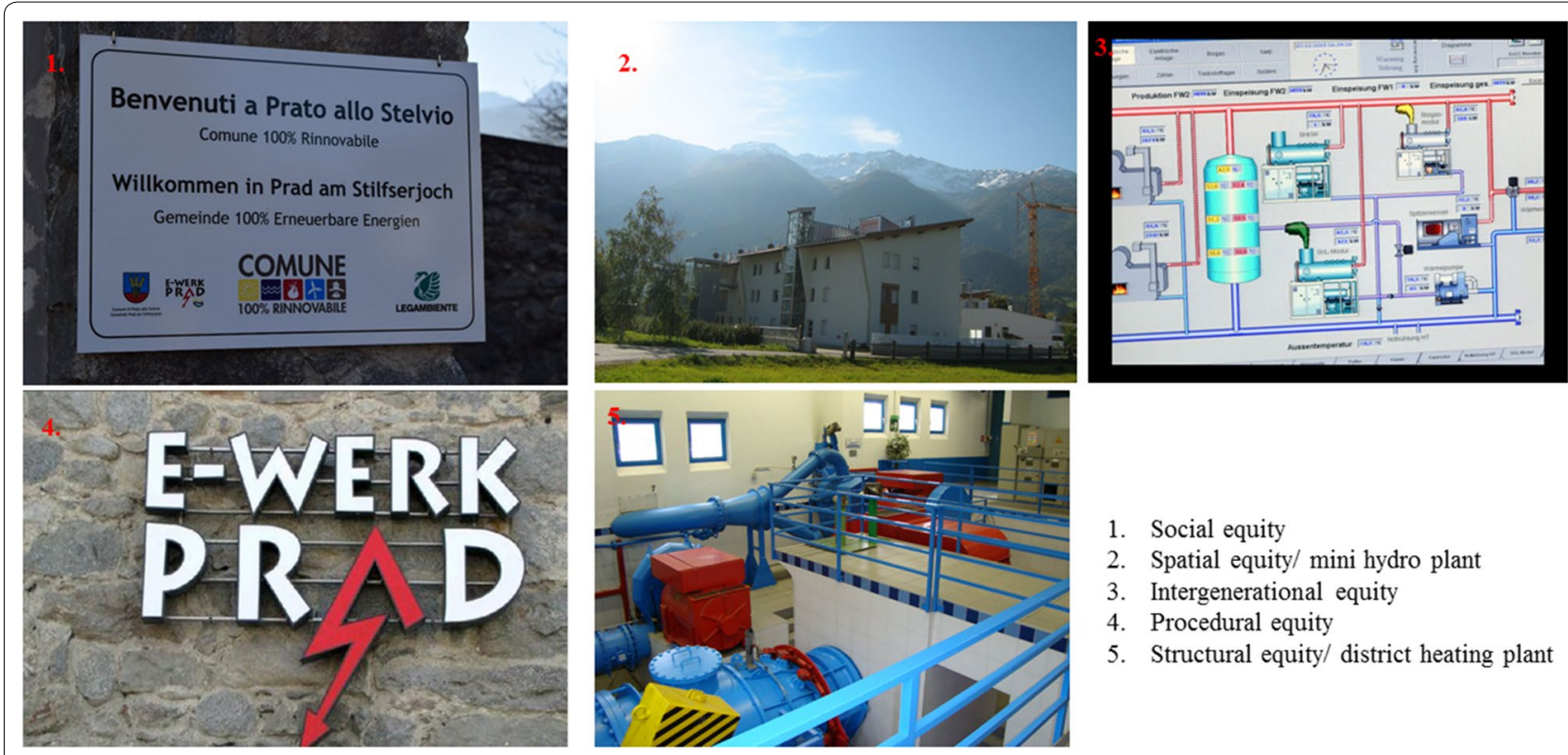

Fig. 3 The principle of equity postulated in a best practice of collaboration and shared choices - City of Prato allo Stelvio and E-Werk Prad Cooperative (Source: 1. http://www.comune.prato.bz.it/system/web/default.aspx?sprache=3-2. http://www.comunirinnovabili.it/comune-di-prato-allostelvio/-3. http://www.e-werk-prad.it-4. http://www.e-werk-prad.it-5. http://www.e-werk-prad.it)

$€$ (compared to about $0.13-0.14$ of a GPL user). In addition to this, we have to consider the indirect advantages: almost all the used biomass is obtained locally, while the money the community saves on utilities gets back in part in the local economy. The Cooperative furthermore manages to earn about 1 million $€$ /year for further development of local networks (Fig. 3).

However, the equity principle is not, always, fulfilled. "In Italy the development of energy, road and waste treatment infrastructures, continue to encounter difficulties and delays for politics-based, popular, environmental and bureaucratic oppositions causing growth slowdown" ${ }^{31}$ What emerges from the NIMBY Forum 2014/2015 shows that the impact on the environment (not respect of intergenerational equity) and procedural and involvement deficiencies (non-compliance with the procedural equity) are the most important reasons that cause opposition to projects. Individuals, committees, organizations, institutions and political parties, promote the protests generally. From the data obtained in 2014 by the Media Observatory, the most widespread protests turned out to be popular ones (32.3\%), i.e. the bottom-up, spontaneous ones in which citizens become protagonists and driving force of events and local initiatives.

\footnotetext{
${ }^{31}$ Cfr. Nimby Forum, Osservatorio Nimby Forum, 10a edizione 2014/2015, Bertello A. (a cura di), Aris-Agenzia di. Ricerche Informazione e Società; http://www.nimbyforum.it.
}

As for the data related to electricity production plants contested in 2014, the absolute evidence is the prevalence of renewable sources plants compared to conventional sources. In 2014, 139 plants for the production of electricity from renewable resources have been contested: this data represents $92 \%$ of the total value. The plants from conventional sources correspond to the remaining $8 \%$.

In particular, among the most contested RES we find biomass power plants ${ }^{32}$ : the cases of dispute concerning this type of system represent $28.4 \%$ of the total. It is mostly small or extremely small plants whose proliferation in Italy was also favored by specific incentive tools and by a simplification of the authorization procedure, that nowadays, for projects up to $1 \mathrm{MW}$ of power, requires only the authorization from the local body (Autorizzazione Unica Provinciale) (Figs. 4, 5, 6).

This research represents a new interpretation of the concept of cultural consensus in relation to energy landscape. In fact, if the energy from RES was perceived as a source of well-being by the community, then it would create new forms of collaboration and cooperation between subjects of different nature that would find an alignment of interests to achieve a common goal. Participation becomes the tool for well-being of individuals

\footnotetext{
${ }^{32}$ See for example, Rodengo Saiano biomass plant in Brescia (Italy): http:// www.bsnews.it/notizia/21581/22-12-2012-Rodengo-Saiano-la-centralebiomasse-prende-vita-e-fa-infuriare-cittadini-e-Legambiente-
} 


\begin{tabular}{||l|l|l|}
\hline Contested plants & Municipality & Province \\
\hline Chiari biogas plant & Chiari & Brescia \\
\hline Casei Gerola biomass plant & Casei Gerola & Pavia \\
\hline Castelletto Borgo biomass plant & $\begin{array}{l}\text { Roncoferraro (loc. Castelletto } \\
\text { Borgo) }\end{array}$ & Mantova \\
\hline Cavernago biomass plant & Cavernago & Bergamo \\
\hline Curtatone biomass plant & Curtatone & Mantova \\
\hline Felonica biomass plant & Felonica & Mantova \\
\hline Rivarolo biomass plant & Rivarolo Mantovano & Mantova \\
\hline Rodengo Saiano biomass plant & Rodengo Saiano & Brescia \\
\hline Turbigo biomass plant & Turbigo & Milano \\
\hline Alto Varrone hydroelectric plant & Premana & Lecco \\
\hline Bedizzole hydroelectric plant & Bedizzole (loc. Barbelli) & Brescia \\
\hline Bertonico hydroelectric plant & Bertonico & Lodi \\
\hline Cadignano hydroelectric plant & $\begin{array}{l}\text { Verolanuova (loc. Fiumazzo a } \\
\text { Cadignano) }\end{array}$ & Brescia \\
\hline Castelnuovo hydroelectric plant & Castelnuovo & Lodi \\
\hline Cortenova hydroelectric plant & Valle dei Mulini- Cortenova & Lecco \\
\hline Pozzolo hydroelectric plant & (loc. Marmirolo) Pozzolo & Mantova \\
\hline
\end{tabular}

Fig. 4 The example of the NIMBY Forum and RES contested plants in Lombardia_excerpt from the table: contested national systems, drafted by the NIMBY Forum Observatory 2014/2015

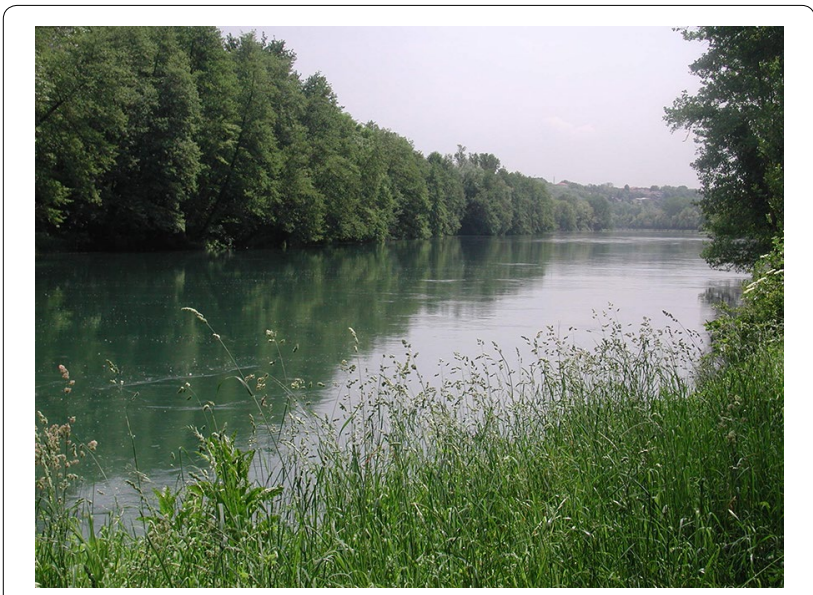

Fig. 5 Failure of intergenerational equity. The stretch of the river Adda, where it should rise the Bertonico hydroelectric plant. The plant has been challenged because the impact on the affected area, would produce the risk of raising the water table in an area that is already subject to phenomena of instability and flooding (Source: https://commons.wikimedia.org/wiki/Adda) and collective transformation, at the same time need and goal, to promote social gathering measures aimed at transformation of life contexts locally.

There are strong connections between the debate on local bottom-up development and the one on sustainable development. Concrete is the hope that local strategies can be oriented and contribute to sustainability creating new theories, approaches and tools. Innovation is not only invention and research capacity but also the ability to create new patterns of social life; it must consider what was produced (energy systems, services, etc.) but also how to produce and how to use what has been produced in the best way (processes, markets, organizations). The relationship between energy systems and landscapes assumes that we consider the concepts of development and innovation as cultural change strategies.

A combination that is able to change the planning and programming horizons thanks to the transition from centralized policies to subsidiarity, to the strengthening of democracy, cooperation, networking, partnership and 


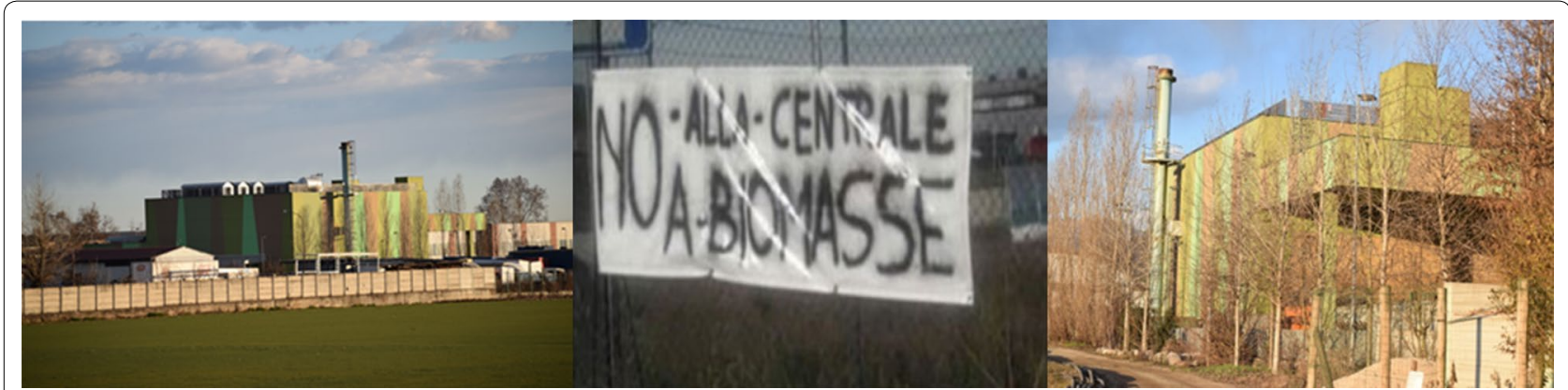

Fig. 6 Failure to comply with procedural equity. The involvement of the population deficiencies for the central biomass plant in Rodengo Saiano (BS) have meant that it was forming a spontaneous protest committee: The opening of the center, in advance of the plan has sparked the ire of the committee "No Central Biomass "accusing the company of not having waited for the results of the checks made by ARPA on the air (Source: http:// www.quibrescia.it/cms)

participation of people, requiring holistic and synergic methods that assume the importance of diversity and unity, limits and well-being.

\section{Authors' contributions}

$A B$ carried out the studies on the social dimension of energy landscapes, system fairness, bottom-up decision-making processes, on the related case studies and frequent NIMBY Phenomena. She defined the new methodology based on cultural consensus and the five aspects of equity and drafted the manuscript. EG defined the methodology of the wider research on the management of the relationship between energy systems and landscape, that represents the basis of this manuscript. She analyzed multifunctionality related to space connected to the spatial equity concept and participated in the sequence alignment. Both authors read and approved the final manuscript.

\section{Author details}

${ }^{1}$ Bologna Business School, Università degli Studi di Bologna, Via degli Scalini, 18, 40136 Bologna, Italy. ${ }^{2}$ Dipartimento di Architettura, Ingegneria delle Costruzioni e Ambiente Costruito, Politecnico di Milano, Via Giuseppe Ponzio, 31, 20133 Milano, Italy.

\section{Acknowledgements}

Not applicable.

\section{Competing interests}

The authors declare that they have no competing interests.

\section{Availability of data and materials}

Not applicable.

\section{Funding}

Not applicable.

\section{Publisher's Note}

Springer Nature remains neutral with regard to jurisdictional claims in published maps and institutional affiliations.

Received: 30 July 2018 Accepted: 17 September 2018

Published online: 01 October 2018

\section{References}

Abramsky K (2010) Sparking a worldwide energy revolution: social struggles in the transition to a post-petrol world. AK Press, Oakland

Armour AM (1991) The Siting of Locally Unwanted Land Uses: Towards a Cooperative Approach. In: Progress in Planning, vol 35
Brovarone F, Putilli M (2008) Territorialità, sostenibilità, rappresentazioni: i paesaggi energetici. Agribusiness Paesaggio \& Ambiente, vol 11. Forum, Udine

Caramis A (2010) Le energie rinnovabili tra obiettivi globali e opposizioni locali: una valutazione retrospettiva. In: Energia Ambiente e Innovazione, 3

Cowell R, Bristow G, Munday M (2011) Acceptance, acceptability and environmental justice: the role of community benefits in wind energy development. J Environ Plann Manage 54(4):539-557

Devine-Wright P, Batel S (2017) My neighbourhood, my country or my planet? The influence of multiple place attachments and climate change concern on social acceptance of energy infrastructure. Global Environ Change 47:110-120. https://doi.org/10.1016/j.gloenvcha.2017.08.003

Di Giovanni E (2000) Nuove complementarietà tra uomo e ambiente. Franco Angeli, Milano

Dincer I, Rosen MA (2007) Exergy, energy, environment and sustainable development. Elsevier, New York

Edwards P, Bowker G, Jackson S, Williams R (2009) Introduction: an agenda for infrastructure studies. J Assoc Inf Syst 10(5):364-374

EEA-European Environment Agency, Energy and environment report 2008, Report No 6/2008

EEA-European Environment Agency, Renewable energies: success stories, Office for Official Publications of the EU Communities, Copenaghen, 2001, Environmental issue report No 27

Elliot D (2003) Energy, society and environment. Taylor \& Francis Group, London

Farina A (2006) II paesaggio cognitivo. Una nuova entità ecologica, Milano

Friedl C, Reichl J (2016) Realizing energy infrastructure projects-a qualitative empirical analysis of local practices to address social acceptance. Energy Policy 89:184-193. https://doi.org/10.1016/j.enpol.2015.11.027

Fusco Girard L (2011) Sviluppo e tutela dell'ambiente per la costruzione della "vita buona" nella città del XXI secolo. In: Ricerca n 7/8. Bimestrale Federazione Universitaria Cattolica Italiana, pp 3-6

Fusco Girard L, Nijkamp P (2004) Energia, bellezza, partecipazione: la sfida della sostenibilità: valutazioni integrate tra conservazione e sviluppo. Franco Angeli, Milano

Fusco Girard L, Salzano I (2005) La promozione delle energie rinnovabili nello sviluppo urbano, vol 29. AEIT, Milano, pp 28-37

Ginelli E, Daglio L (2014) Energyscapes: developing a multiscalar systemic approach to assess the environmental, social and economic impact of renewable energy systems on landscape. In: Proceedings of the 2 nd ICAUD International Conference in Architecture and Urban Design. Epoka University, Tirana, pp 152/1-152/8

Ginelli E, Daglio L (2014b) Relationship between energy systems and landscape. Guidelines and tools for design and management, vol 8. TECHNE, Bologna

Ginelli E, Daglio L (2015) A multidimensional analysis to manage the relation between energy and landscape. In: The Fifteenth International Conference on Civil, Structural and Environmental Engineering Computing, Prague. Edit in CIVIL-COMP PRESS. http://civil-comp.com/conf/conf2015/ cc2015.htm. Accessed 1 Sept 2015 
Huber N, Hergert R, Price B et al (2017) Renewable energy sources: conflicts and opportunities in a changing landscape. Reg Environ Change 17:1241. https://doi.org/10.1007/s10113-016-1098-9

Hunter Lovins L, Cohen B (2011) Climate capitalism: capitalism in the age of climate change. Hill and Wang a division of Farrar, Straus and Giroux, New York

Kaygusuz K (2007) Energy for sustainable development: key issues and challenges. Energy Sources Part B 2(1):73-83

Kellet J (2007) Community-based energy policy: a practical approach to carbon reduction. J Environ Plann Manage 50(3):381-396

Kleinman DL (2000) Sci Technol Environ. Suny Press, New York

Koch R, Brunner C, Hacker J, Urschik A, Sabara D, Hotwagner M, Aichernich C, Hofbauer HWR, Fercher E (2006) Energieautarker Bezirk Güssing. Vienna, Bundesministerium für Verkehr Innovation und Technologie (In German)

Laurent-Lucchetti J, Leroux J (2007) Why me? Siting a locally unwanted public good. In: Cahier de recherche n. IEA-07-14. HEC Montreal, Montreal

Mallett A (2007) Social acceptance of renewable energy innovations: the role of technology cooperation in urban Mexico. Energy Policy. https://doi. org/10.1016/j.enpol.2006.12.008

Marchigiani E, Prestamburgo (a cura di) S (2010) Energie rinnovabili e paesaggi: strategie e progetti per la valorizzazione delle risorse territoriali. Franco Angeli, Milano

Marchigiani E, Prestamburgo S (2012) Energie rinnovabili e paesaggi. Franco Angeli, Milano

Melis B (2010) Smart energy in Social Energy: to overcome isolation. Create a knowledge network through technological innovation to connect building and neighborhood, user and society. In: Inhabiting the future... after Copenhagen, Giornata internazionale di studi. Clean, Napoli

Miller, C. (2012) Energy justice: ensuring human dignity in the post-carbon future. Cairo Review of Global Affairs, May: 46-59
Murphy BL, Kuhn RG (2006) Scaling environment justice: the case of the waste isolation pilot plant. In: proceedings of values in decisions on risk (VALDOR), Stockholm

Phadke R (2013) Public deliberation and the geographies of wind justice. Sci Cult. https://doi.org/10.1080/09505431.2013.786997

Rand J, Hoen B (2017) Thirty years of North American wind energy acceptance research: what have we learned? Energy Res Soc Sci 29:135-148. https:// doi.org/10.1016/j.erss.2017.05.019

Robertson R (1992) Globalization, social theory and global culture. Sage, London

Sclove R (1995) Technology and democracy. Guilford Press, New York City

Steg L, Van Der Berg AE, De Groot JIM (2013) Manuale di psicologia ambientale e dei comportamenti energetici. Ferrarisinibaldi Edizioni, Milano

Walters CJ (1986) Adaptive management of renewable resources. Collier Macmillan, New York

Wienke U (2001) L'esempio del quartiere Vauban a Friburgo. In: Living Land n 10. Salute e Architettura Editore, Torino

Wolch J, Dear M (1993) Malign neglect: homelessness in an American city. Jossey Bass, San Francisco, CA

Wolsink M (2007a) Planning on renewables schemes: deliberative and fair decision-making on landscape issues instead of reproachful accusations of non-cooperation. Energy Policy 35(5):2692-2704

Wolsink M (2007b) Wind power implementation: the nature of public attitudes: equity and fairness instead of 'backyard motives'. Renew Sustain Energy Rev 11:1188-1207

Wüstenhagen R, Wolsink M, Bürer MJ (2007) Social acceptance of renewable energy innovation: an introduction to the concept. Energy Policy 35(5):2683-2691

\section{Submit your manuscript to a SpringerOpen ${ }^{\circ}$ journal and benefit from:}

- Convenient online submission

- Rigorous peer review

- Open access: articles freely available online

- High visibility within the field

- Retaining the copyright to your article

Submit your next manuscript at $\boldsymbol{s p r i n g e r o p e n . c o m ~}$ 